\title{
BUSINESS PURPOSE AS A TAX AVOIDANCE CONDITION IN CORPORATE REORGANIZATIONS
}

Marciano Buffon

PhD in Law - emphasis on Public Law - UNISINOS, research period at the University of Coimbra - Master in Public Law. Tax expert lawyer, with specialization in corporate law. Tax Law Professor at UNISINOS courses and Postgraduate (specialization) in Tax Law in other institutions.

Isaías Luz da Silva

LL.B. UNISINOS with interchange program for Washington University in Saint Louis. Federal Public Servant at Procuradoria-Geral da Fazenda Nacional (PGFN).

isaiasluz@hotmail.com

\begin{abstract}
With the approval of the general norm of tax avoidance in the national tax laws, there are several judgments of the Administrative Council of Tax Appeals - Conselho Administrativo de Recursos Fiscais (CARF), which have used a tax avoidance institute of comparative law to consider specific practices resulting from companies' mergers, splits or amalgamation as abusive tax planning. It is known as the "business purpose doctrine", which has been running the Counselours of the CARF to establish limits on the exercise of business activity, but still little discussed by the Brazilian doctrine. In summary, this new approach seeks to prevent that corporate transactions of this kind are carried out with the purpose of building a diverse legal reality of the factual, under the cover of legal formalism. The legality in corporate reorganizations focusing on the business purpose theory has been subject of compliance with three basic requirements: the temporality of business, the interdependence of the parties and the normality of the operation. In spite of the controversies regarding the legitimacy of the institute, it is noted that adopting a business purpose test seems plausible, once the institute is identified with the cause of the legal business.
\end{abstract}

Keywords: Tax planning - Tax avoidance - Business purpose - Corporate Reorganization - Legal Fact 


\section{INTRODUCTION}

This article addresses the construction of the business purpose doctrine, which is an American jurisprudential creation within the Brazilian Legal System from the perspective of the civil law and the criteria adopted by the Secretaria da Receita Federal do Brasil (SRFB), Brazilian Treasury Administration, to the application of the previously mentioned doctrine in administrative decisions. One must remember that the business purpose corresponds to the legal act that must pursue an economic purpose, with primary objetive of optimizing company's business, and not the simply get tax savings. From this perspective, the paper intends to examine the posture adopted by the Administrative Council of Tax Appeals - Conselho Administrativo de Recursos Fiscais (CARF) towards the business purpose, in order to verify whether the understanding which has been prevailing finds lodgement in the Brazilian law.

To facilitate such assignment, we analyse first, the conception of the general norm of tax avoidance, designed to refrain abusive tax planning in the legislation of other countries, including the development of the American and English judicial construction doctrine, based primarily in commercial purpose. Referred to as business purpose or business purpose test doctrine in American law, the doctrine of business purpose - also called doctrine of use negotiation among Brazilian scholars - was created in 1935 by the American Supreme Court, to guide the tax planning in American administrative and judicial field, setting the criteria for legality and illegality in corporate affairs.

Despite the divergence between the Brazilian legal system and the Common Law, CARF, monitoring the evolution of tax avoidance in many other legal systems around the globe, brought the business purpose test to the Brazilian legal system, althought under other figures related to the tax planning field, as a way to legitimize unreasonable administrative requirements in order to file appeals before the CARF, triggering several controversies in the doctrine. However, as noted in the second part of this study, the Brazilian administrative jurisprudence has built criteria other than those adopted by the Americans Courts applying the test of negotiable usage.

It is admissible within the Brazilian tax doctrine to say that the institute created by the Supreme Court and the American tax administration corresponds to the objective element of the tort cause of the legal transaction, which is why the tax administration would be able to implement it in their trials. This is what we examine in the third part of this study. 


\section{BUSINESS PURPOSE: A HISTORICAL APPROACH}

When one intends to examine an issue that involves taxation thre is invariably the risk of meeting antagonistic positions, strongly advocated by their heralds. It is undeniable, a branch of the Law characterized by the constant and ongoing conflict between the state and the taxpayer, and this confrontation is particularly apparent when examining the matter regarding the distinction between tax avoidance and evasion.

Historically, the characterization of evasion, therefore legitimate, has been the subject of endless discussions, mainly regarding its characterization. Specifically with reference to corporate reorganization, these legal disputes have been gaining increasing relevance in a globalized market, where competitors seek to ensure for themselves a more favourable tax treatment.

The classic distinction between avoidance and evasive actions, based solely on the criteria of temporality of the operation and the lawfulness of the behaviour adopted, became insufficient for the solution of several disputes that have emerged over the years. We can understand this as the cause of the Brazilian Complementary Law No. 104, of January 10, 2001, which introduced the Sole Paragraph of Article 116 of the Código Tributário Nacional (CTN), Brazilian National Tax Code, and the official text is as follows:

Art. 116, Parágrafo único. A autoridade administrativa poderá desconsiderar atos ou negócios jurídicos praticados com a finalidade de dissimular a ocorrência do fato gerador do tributo ou a natureza dos elementos constitutivos da obrigação tributária, observados os procedimentos a serem estabelecidos em lei ordinária. ${ }^{l}$

With the emergence of a legal provision in the CTN, the SRFB would be allowed to disregard the acts and legal transactions executed by the taxpayer when these instruments were supported by commercial or economic acts that did not represent the reality of the business between the parties, in other words, the occurrence of a dissimulation, provided that existed an ordinary law setting the respective procedures.

According to Aurelio Pitanga Seixas Filho, the legislator chose to move away from the term simulation because it bears the sense of abuse of

1 Art. 166, Sole paragraph: The administrative competent authority may disregard acts or legal transactions with the purpose of concealing the triggering event of the tribute or the nature of the constitutive elements of the tax liability, subject to the procedures to be established in ordinary law. 
the legal form or breach of the law, so that the word dissimulation would correspond to a disguise or concealment (SEIXAS FILHO, 2003, p.163).

Hence, it is said that the word dissimulation expresses the idea of concealing, hiding something in craftiness to misrepresent or disguise (FERREIRA, 1986, p.483). Therefore, the legal acts or business carried out by the taxpayers in a concealed or disguised form could be decharacterized by the Tax Administration.

Once the SRFB was able to disregard the acts or business carried out by taxpayers for tax purposes, the doctrinal portion advocated by the economic interpretation of Tax Law led to a state that the provision created an axiological evolution due to the open structure of types in the tax legislation (PORTO, 2012, p.155).

Not for reasons other than facing these issues, it prompted discussions in the administrative doctrine and courts related to tax avoidance and tax elision of the dispositive aforementioned rule.

With respect to the sole paragraph of article 116 of the aforementioned legislation, the doctrine was divided into two trends of thought. The first, headed by Alberto Xavier de Couto, stated that the sole paragraph of article 116 was about the anti-avoidance rule, because if it were about the norm of tax avoidance, it would conflict with the taxation principle of close tipicity. The second trend, headed by Marco Aurelio Greco, argued that the sole paragraph is about the norm of tax avoidance, under the guidance of the norm of tax avoidance rules in comparative law (specific tax avoidance rule) that act in fighting law evasion (Germany, Spain, Portugal), abuse of rights (France) or the supremacy of form-over-substance doctrine (USA, UK, Canada etc.) (TORRES, 2012, p.03).

The supporters of the economic interpretation of the Tax Law, in line with Marco Aurelio Greco, argue that the disposition is a norm of tax avoidance, because the tax planning will be lawful when there is no abuse of rights, and, if it occurs, the tax administrator may intervene in transactions among individuals to disregard the act or transaction made. Conversely, there are those who understand that the economic interpretation is unconstitutional because it offends the legality and close and formal structures of Tax. (PORTO, 2012, p.155).

Overcoming the disagreements, the characterization of the tax planning associated to the concepts of tax avoidance and tax evasion became obsolete by the classical distinction of temporality and lawfulness in the legal system, since in the contemporary tax setting, the scope of the discussion turns towards abusive tax planning, envisioning an interpretation of Tax Law that seeks fair taxation. (GOMES, 2005, p.503).

Given this scenario, the doctrine and the legislation of several coutrines were gradually created beacons to restrain abusive tax planning. In Germany, the thresholds for prohibiting the abuse of the legal 
form were enforced through a norm of tax avoidance established with the Taxation Code of 1919 (Reichsabgabenordung - RAO) and later modified in 1977 through the article 42 of the Tax Law of Adaptation, which establishes:

(1) Tax Law cannot be rigged by the abuse of the legal forms. Whenever abuse occurs, the claim of the tax will appear as the economic phenomena had been adopted the appropriate legal form. (2) The abuse occurs when an inadequate juridical structure is selected $[\ldots]{ }^{2}$

In the Spanish law, the prohibition of fraud to the law was given by Article 24 of the Lei General Tributaria, amended by Law 25 of July 20,1995, which allows the tax authorities to consider fraud to the tax law, or tax demand object of tax avoidance, as shown in the transcript below:

Para evitar el fraude de ley se entendera que no existe extensión del hecho imponible cuando se graven hechos, actos o negócios jurídicos realizados com el propósito de eludir el pago del tributo, amparándose en el texto de normas dictadas com distinta finalidade, siempre que produzcan um resultado equivalente al derivado del hecho imponible. El fraude de ley tributaria deberá ser declarado en expedbuto iente especial em el que se dé audicencia al interessado.

Similarly, the General Portuguese Tax Law (Lei Geral Tributária), article 38, item 2 also establishes prohibiting the breach of the law.

São ineficazes no âmbito tributário os actos ou negócios jurídicos essencial ou principalmente dirigidos, por meios artificiosos ou fraudulentos e com abuso das formas jurídicas, à redução, eliminação ou diferimento temporal de impostos que seriam devidos em resultados de factos, actos ou negócios jurídicos de idêntico fim económico, ou a obtenção de vantagens fiscais que não seriam

2 Translation to Portuguese by Alfred J. Schmdt in "TORRES, Ricardo Lobo. Normas gerais antielisivas. Revista Eletrônica de Direito Administrativo Econômico, Salvador, Bahia, n. 4, nov./dez. 2006. Available at: < http://www.direitodoestado.com/ revista/REDAE-4-NOVEMBRO-2005RICARDO\%20LOBO\%20TORRES.pdf>. Entry: 02 May 2014." 
lançadas, total ou parcialmente, sem utilização desses meios, efectuando-se então a tributação de acordo com as normas aplicáveis na sua ausência e não se produzido as vantagens fiscais referidas. ${ }^{3}$

In the Argentinian legal system, the institution of the norm of tax avoidance happened through the "doctrina de la penetration", or disregard of the legal entity, which authorizes the tax authorities to mischaracterize the legal personality of the company to meet the substance of the business and the liability of shareholders.

In Italy, the tax authorities have the power to mischaracterize the tax advantage acquired via corporate operations when there is no specific reason that certain economics is valid or when a fraudulent purpose from the taxpayer occur in order to save on taxes.

In many countries including such as the United States of America, Canada, England, Australia and Sweden it was developed a doctrine prompted by the business carried out between the parties, called doctrine of business purpose, business purpose or negotiating purpose, result of judicial construction in the United States of America and England (anti avoidance rules) or legislation in Canada, Australia and Sweden (GOMES, 2005, p.503).

In Canada, the norm of tax avoidance is enforced when it is abusive. The general anti-avoidance provision of the Canadian law allows the Internal Revenue Service (IRS) to deny tax benefits that result either directly or indirectly from operations, if it understands these were not carried out in a reasonable manner (AMARAL, 2002, p.296).

In Sweden the norm of tax avoidance takes place through three criteria which identify the imperfection in tax avoidance: a) legal business carried out by the parties is uncommon; b) incidence of significant tax savings c) evident purpose of reducing the tax burden without other legitimate reasons (business purpose) (DÓRIA, 1977, p.75).

In the United Kingdom (UK), the norm of tax avoidance arose through jurisprudential understanding of two significant cases of the tax planning industry: the Ramsay and the Furniss cases (Amaral, 2002, p.295). In the former, the taxpayer sought the sale of a property to a given buyer without paying taxes in England, transferring the property to a Tax Haven (Mann Island) to ensure that the company would sell

3 Ineffective under the Tax Acts or essential or primarily for legal transactions, by artificial or fraudulent means and abuse of legal forms, reduction, elimination or deferral of taxes that would be payable as a result of facts, acts or legal transactions of identical economic, or derive tax benefits which would not be reached wholly or in part, without the use of these means, taxing in accordance with the applicable rules in its absence and did not produce the tax benefits mentioned. 
the property directly to the buyer in England (circuit operation). In the Furniss case, a determined English taxpayer sold the property to a company located in the Isle of Man, and they sold it to another taxpayer characterizing capital gain.

The House of Lords, a higher British instance, when analysing both instances, ruled that in Ramsay's case the operation would be disregarded because of the fact that there was a purchase and sale business. In the Furniss case, the Court ruled that the transaction was valid because there was no specific buyer, so that there was no circular structure of the business, as in the first case, in other words, unequivocal purpose of obtaining economic advantage and prejudicing the Tax Statute (AMARAL, 2002, p.296).

Based on this context, it is consolidated in the British courts the so-called Ramsay Principle, explained here by Túlio Rosembuj:

Según Lord Oliver, em el caso Ramsay se enuncia el principio de que los tribunales pueden considerar transaciones individuales como 'un todo' $y$, por tanto, como um plan organizado para eludir impuestos; que este plan organizado puede estar formado por transaciones (contratos, operaciones, etc) artificialmente concertadas para obtener um resultado diferente, em su conjunto, del que se habría producido de no existir tal conexión; que es importante establecer si en algunas de essas transaciones falta um objetivo comercial; que es suficiente para tener uma preorganización elusiva, uma 'voluntad guía' que pueda garantizar que los diferentes passos sucesivos serán llevado a cabo. (ROSEMBUJ, 1999, p.380).

However, it is the enactment of the business purpose doctrine in the American jurisprudence that establishes a landmark in the setting of tax planning (GODOY, 2003, p.61).

Notwithstanding, the construction of the business purpose doctrine was established by the intention to consider abusive a tax avoidance when the taxpayer in pursuit of tax advantages diverges from the purpose of the business in the area. This is a test created by by the Yankee precedent whose goal is to analyse whether the transaction would have been performed in the same manner if there had been no tax advantages. (SCHOUERI, 2010, p.18).

The doctrine was developed by the North American courts from the idea of the substance-over-form concept, which implies that 
the business acts or transactions must show the reality of the entity (economic substance of transaction), rather than their legal form (form), in order to present a true and fair view of the affairs of the entity (AMARAL, 2002, p.294).

In this perfunctory review, in the next topic, we will study the origin of the business purpose doctrine and its unfolding in American jurisprudence.

\section{BUSINESS PURPOSEDOCTRINEINTHENORTHAMERICANLEGALSYSTEM}

Among those several institutes established by judge-made law in the United States, it gains in relevance the business purpose test, in the subject matter of this study, which enables, in greater amplitude, the analysis of the legality and illegality of tax elision.

This test was designed in 1935 by the North American Supreme Court with the trial of the case Gregory v. Helvering (293 U.S. 465, 1935 ) in order to judge whether a given commercial transaction entered into the taxpayer, Ms. Gregory, was in fact, of economic substance (MACHADO, 2013, p.70).

Arnaldo Sampaio Moraes Godoy says that in at the time of the trial - which dates from December, 1934 to January, 1935 - the United States of America was going through a major economic crisis, still struggling with the recession of 1929. The institutional image of the country needed to be reinstated by adopting pedagogical measures that undermined the commercial law of 1920 and the Supreme Court was the ideal setting for this intent (GODOY, 2003, p.61).

In summary, as we can conclude from the decision and the reviews of the jurist cited above, the taxpayer, Mrs Evelyn Gregory, owned all shares of United Mortgage Corporation. The company had 1,000 shares of the Monitor Securities Corporation in assets with a market value that exceeded the book value, which is why she wanted to alienate them to have direct access to the proceeds from the disposition. At first, the taxpayer could distribute the shares of the Monitor to herself to alienate them later, which would result in the taxation of dividends in the shares.

Thus, Ms. Gregory articulated a corporate restructuring as set forth in section $112(\mathrm{~g})$ of the Income Tax Law, 1928 to transfer the shares to herself, with the aim of reducing the amount of income tax when transferring the shares directly. This norm exempted taxation in cases where a given company by means of a corporate transaction, transferred shares to its shareholders who held shares in another company.

Next, the taxpayer created a new company called Averill Corporation, to which she transferred the shares held on behalf of Monitor Securities, dissolving, in sequence, the company Averill, and 
thereafter distributing the assets to herself.

The US Treasury, by carefully examining the case, noted that the company Averill, established through a corporate transaction, never possessed substance and thus, its existence should be disregarded, even though the taxpayer had not directly circumvented the legislation.

Although in the administrative court - The Board of Tax Appeals - the view of the tax administration was rejected, the Court of Appeals The United States Court of Appeals for the Second District - reformed the decision, considering that even though, the operation occurred according to the law, the deal did not meet the legitimate business purpose.

In the opinion of the Supreme Court, although the taxpayer was entitled to reduce or plan their taxes, they could not do so if the act practiced did not harmonize with the intent of the legislator, as seen in the excerpt transcribed below:

The legal right of a taxpayer to decrease the amount of what otherwise would be his taxes, or altogether avoid them, by means which the law permits, cannot be doubted. [...] Bur the question for determination is wheter was done, apart from the tax motive, was the thing which the statute intended. ${ }^{4}$

Thus, resulting in unfavourable trial to the taxpayer, we agreed that the Supreme Court:

(1) Minimization, Avoidance or Evasion of Liability: Taxpayer can decrease the amount of his taxes or altogether avoid them within what the law permits. (2) Acts Constituting Reorganization in General: Transfer of some corporation assets owned in full by the taxpayer, to the new corporation, created solely with the purpose of receiving and transferring assets to the taxpayer as liquidating dividend, after which the new corporation was dissolved, and reorganized within the statute, being exempt from the tax gain arising from the transfer of assets by one corporation to another corporation pursuant of reorganization. Revenue Act 1928, § 112(g), (i) (1), 26 U.S.C.A., \& 112. (3) Plan of Reorganization: Under statute exempting from tax gain arising from the transfer of assets by one corporation to another, 'transfer'

4 UNITED STATES. Supreme Court of the United States. Gregory v. Helvering, Comissioner of Internal Revenue. No. 127 Mr. Justice Sutherland. Decided on January $1^{\text {st }}, 1935$. Published in 55 S.Ct. 266.Available at: $<$ https://a.next.westlaw.com/ Document/I47>. Entry: 15 out. 2013. 
must be made pursuant to plan of reorganization and not pursuant to plan having no relation to business of either corporation. Revenue Act 1928, C(g), (i) (1) 26 U.S.C.A. $\S 112$.

The trial of the case by the Supreme Court was crucial to raise the business purpose doctrine to a norm of tax avoidance by imposing limitations on tax planning carried out in the U.S.

In this aspect, the business purpose doctrine asserts that transactions will not be valid when the only purpose of these cases is tax savings unless they intended to reach a valid and independent negotiation use. In these cases, the tax administration, in the absence of a negotiating reason, can disregard the operation, even though they are in compliance with the tax legislation (JONES, 1999, p.73).

Thus, it is observed that the tax administration and the North American Courts seek to avoid the tax advantage by companies that are dissociated from the legal business usefulness the company with the mere motivation of overturning the tax, according to Tulio Rosembuj:

\begin{abstract}
El business purpose test, em los EE UU resulta aplicado por los Tribunales para descalificar o declarar la ineficácia de determinadas actividades o negócios jurídicos cuya finalidade o alguna de las fases de los mismos, aun cuando sea verdaderas no son apropriadas ni necessarias a la empresa, dirigidos como están a obtener uma situacion de ventaja tributária (ROSEMBUJ, 1999, p.261).
\end{abstract}

At the Institute of business purpose, the tax administration searches for a business purpose in the legal act accomplished by the taxpayer. The economic reality is essential for the implementation of the institute element, since the purpose, which is sought, is the one that rules the exercise of the business activity (MACHADO, 2007, p.48).

According to Hermes Marcelo Huck, "the economic significance of the legal transaction is essential, and not being found, it is lawful for the IRS to tax the covert operation by the business ostensibly presented" (HUCK, 1997, p.200).

Antonio Roberto Sampaio Dória explains that the recognition of the business purpose doctrine in corporate business occurs by applying three tests: a) the test of permanence; b) the test of corporate advantage and c) the test of fiscal savings (DÓRIA, 1977, p.78). The first test aims to prove that what does not fall under the definition of "reorganization" of corporate transactions, cannot extend their activities. The second test determines that the reorganization should provide benefits to the 
surviving corporation, in order not to allow that such benefits directly influence the business owners. Lastly, the third test involves the corporate operations whose purpose is the reduction of taxes, which are not considered reorganizations within the legal directives.

Despite the birth of the business purpose doctrine in trial elsewhere, the so-called model of substance-over-form thrived-up from its advent.

It is a construction of the Internal Revenue Service, the North American Inland Revenue, and the Federal Courts, to ensure that taxpayers pay attention to the spirit of the law - their real purpose, and not just the normalized legal form as explains Sally M. Jones:

The substance-over-form doctrine says that the IRS is entitled to look through the legal formalities to determine the true economic substance (if any) of a transaction. If the substance differs from the form, the tax consequences of the transaction will be based on the reality rather than the illusion (JONES, 1999, p.73).

The doctrine of substance over form operates to prevent the very nature of the transaction to be covered by mere legal formalities, which can be used to circumvent tax obligations, and promote effective governance of the legislative policy and the intention of the legislator.

The aforementioned understanding is used as support for the business purpose doctrine in common law countries, since it establishes the limits for use in business arrangements artificially established, as Raoul Lenz explains:

The Anglo-Saxon law, based on the precedents, developed a doctrine that considers the business substance more relevant than the form. When applying this doctrine, the court seeks the 'substance' of the transaction, which means the true purpose of the business. If the true substance is remarkably different from the form attributed to the operation, and if this form has the sole purpose to save taxes, the operation is considered simulated and is requalified in accordance with its true substance (LENZ, 1988, p.588).

In the American legal system, the doctrine of the business purpose and the substance-over-form, together, are applicable three categories: a) sham transactions, in which the business purpose test 
is used to disregard the corporate or the benefits obtained when the only goal is motivated by tax savings and a corporate transaction did not need be accomplished; b) transactions out of the economic reality, which, though practiced within the legal boundaries, are unrealistic because the tax consequences are the cause of their structuting, and last c) step transactions in which taxpayers employ the most complex tax legislation to perform operations in series, where the tax administration may disregard every step if the operation is considered as a whole. (MACHADO, 2013, p. 73).

In view of these considerations, the follow-up to this study assesses the association of the business purpose in the administrative decisions of the tax bodies, and later their presence in judicial decisions, which will provide a better understanding as an instrument adopted by the tax administration for tax avoidance viability in corporate reorganizations.

\section{THE (DES) CONSTRUCTION OFTHE BUSINESS PURPOSE DOCTRINEIN THE BRAZILIAN JURISDICTION}

Despite the contrasts between the continental and common law jurisdiction, it has been observed, especially following the introduction of the sole paragraph of article 116 of the CTN, the adoption of the business purpose doctrine and its variations in the trials of the CARF (or former Câmara Superior de Recursos Fiscais ${ }^{5}$ ), albeit under the designation of other theories, such as circumvention of the law or abuse of rights (SCHOUERI, 2010, P. 18).

In this light, the theory of the business purpose is being used to legitimize tax avoidance practices under the umbrella of the Homeland Legal Order, as Andrade Filho affirms:

Strictly speaking, this idea corresponds, in substance, to the enforceability of an 'extra tributary reason' to justify certain tax avoidance practices and, without the existence of such reason the taxpayer could not justify practices only from considerations about the legality of the means and forms. On the other hand, under the same perspective, the sole purpose of obtaining an optimization of the tax burden would not be catalogued as a valid business purpose (ANDRADE FILHO, 2009, p.200).

The business purpose gained enormous prominence in the

5 The change in nomenclature for the CARF happened with the issuance of the Provisional Measure No. 449, converted into Law 11,941 of December 27, 2009. 
trials of the CARF from the Provisional Measure No. 66/2002, which regulated the administrative procedure determining the disregard acts or legal transactions for tax purposes. ${ }^{6}$

Thus, that provision aimed to complement the sole paragraph of art. 116, establishing the absence of business purpose or the instance of abuse in order to disregard acts or legal transactions by the tax administration, as seen in the transcript excerpt below:

Art. 14. Are likely to disregard the acts or legal businesses that aim to reduce the amount of tax, prevent or delay their payment or conceal the true aspects of the triggering event or the real nature of the constituent elements of the tax obligation.

$\S 1^{\underline{0}}$ For the disregard of legal business act or legal business it should take into account, inter alia, the occurrence of I - lack of business purpose; II- abuse of form.

The second paragraph of the aforementioned rule, tries to make a legal provision the requirement of the business purpose in the national tax legislation, specifying the extent of non-occurrence of the business purpose in acts or legal transactions.

\section{$\S 2^{\circ}$ It is considered an indication of absence of business purpose the option for more complex or costly, to those involved, between two or more ways for the practice of certain legal instrument.}

The art.14 of the Provisional Measure No. 66/2002, which elected the absence of business purpose and the abuse of form to disregard the acts and legal business, did not flourish under the national law, because a particular part of that rule was not converted into law. ${ }^{7}$

Notwithstanding the non-conversion of the Provisional Measure was no hindrance for the Secretaria da Receita Federal do Brasil (SRFB), Brazilian Treasury Administration, to remain applying the North American doctrine in their decisions, albeit under the alias of other figures of tax legislation (SCHOUERI, 2010, p.19).

The attempt of the former Conselho de Contribuintes/CSRF to build the thesis of the business purpose in its judgments, even

6 BRASIL. Provisional Measure No. 66 of Augusto 29, 2002. It comprises on the procedures to disregard acts or legal transactions for tax purposes. Available at $<$ http://www.receita.fazenda. gov.br/Legislacao/MPs/2002/mp66.htm>. Entry: 11 May 2014.

7 The Provisional Measure $n^{\circ}$ 66, of 29 August 2002, was subsequently converted into Law 637, of December 30, 2002. 
"unauthorized" by the Legislative Power, stirred controversy in the field of the tax planning, mainly over the (in) compatibility of their implementation in the Brazilian legal systematic ahead to the principle of trict legal types and legal certainty, according to Hugo de Brito Machado:

The business purpose requirement for the validity of acts or legal transactions to the tax authorities, which gained strength from the Provisional Measure No. 66, is an intolerable limitation of freedom of the taxpayer, being rejected even by the most favourable doctrine to Treasury in terms of tax planning. The worst, however, is that the rejection by the National Congress of the dispositions from the Provisional Measure, which were under their care, appeared to be a victory against the discretion, but in practice it ended up as a pathway to its aggravation, as will become clear below (MACHADO, 2007, p.51).

Prior to the issuance of the tax avoidance norm, the former Conselho de Contribuintes/CSRF embraced the principle of types and of the strict tax legality in their judgments, so that the mere compliance with formalities of the legal transaction characterized the legality of the transaction, that is, the legality of the act was intrinsically connected to compliance of the legal business to the law. ${ }^{8}$

By the principle of tax legality, the SRFB is obligated to crate and collect taxes in cases prescribed by the law as the state intervention in deed, property and the rights of the taxpayer may only be authorized by means of a judicial act (CARRAZA, 2010, p.278).

With the advent of the norm of tax avoidance, the former Conselho de Contribuintes/CSRF - currently CARF - strongly changed the way it understands the legal transactions practiced by the companies.

In fact, CARF is adopting the analysis of the absence of business purpose in the legal business, so as to determine if the validity of the corporate transaction is tied to certain indications "business motivation" and its legality", which means to say that a given operation should present a practical purpose, a negotiating rationale so that it takes place (HUCK, 1997. p.49).

8 In this sense see the judgements number 103-21.047 (10/2002), 101-93.616 $(09 / 2001)$ and 106-09.343 (09/1997) the old Board of Contributors.

9 In this sense see the judgements $1103-000.960$ (05/2014), 1102-001.018 (03/2014), 1401-001.059 (01/2014), 1402-001.229 (04/2013), 1202-000.884 (04/2013), 2202002.187 (02/2013), $1402001.103 \quad(08 / 2012), \quad 1402-001.078 \quad(08 / 2012), 1402-$ 001.080 (07/2012), 1402-01.078 (06/2012), 1201-00.548 (08/2011), 2202-001.217 (06/2011), 9202-01.194 (02/2010) and 103-23290 (12/2007) the former Conselho de Contribuintes. 
In a recent study conducted through the analysis of several trials of the former Conselho de Contribuintes/CSRF, Luis Schoueri found what indications of business purpose are admitted by the tax administration. The study revealed that there are three criteria considered by the SRFB to verify the absence of business purpose: the time lapse, the interdependencies of stakeholders and abnormal operations (SCHOUERI, 2010, p.482).

The first criterion is guided by the period of time in which the operation is performed, usually considered in corporate reorganizations performed in a hurry or on the same day. In such cases, the CARF understand that there is absence of business purpose when operations are performed without the necessary time for decisions to be made within the formalities that society demands, as seen in Case No. 10614486, in the excerpt from of the vote of the Councillor Efigênia Sueli Mendes de Britto:

A transaction such as the transfer of the enterprise Freios Borges $S / A$, because of its importance and the value of the operation is not performed in a few days but in months, after many adjustments. The sequence of operations that were done fast is the strongest indication that all operations were performed in order to prevent the triggering event of the principal tax liability, to exclude or modify their essential characteristics in order to reduce the amount of tax due. ${ }^{10}$

The second criterion is measured by the interdependence between the parties involved. Herein, the judges observe whether the operations are being conducted between different companies or between the same economic groups, as shown in the summary of the judgment $\mathrm{n}^{\mathrm{o}} 1803-000.551$ :

\section{FINE LETTER-SUCCESSIONBYINCORPORATION- SUCCESSOR LIABILITY-SUCCESSION AMONG}

10 BRASIL. Ministry of Finance. Judgment n. 106-14486. Applicant: Marina Varga Carvalho. Defendant: 3rd Class DRJ in Brasilia. Drafter: Efigênia Sueli Mendes de Britto. Brasilia, March 16, 2005. Available :<https://carf.fazenda.gov.br $>$. Entry: 12 May 2014. Translation: "Uma operação como a alienação da empresa Freios Varga S/A, por sua importância e pelo valor da operação, não é realizada em alguns dias, mas em meses, depois de muitos ajustes. A seqüência de operações realizadas a toque de caixa é o mais forte indicio de que todas as operações foram realizadas com o fim de impedir a ocorrência do fato gerador da obrigação tributária principal, ou a excluir ou modificar as suas características essenciais de modo a reduzir o montante do imposto devido". 
ENTERPRISES CONSTITUENT OF THE SAME GROUP-DISCLAIMER-IMPOSSIBILITY-In the case of intercompany succession, affiliated or subsidiary, one should keep the fine letter drwan to the incorporated company should remain intact, since the intervention of the developer company on the procedures of the incoporated compony is notorious. ${ }^{11}$

The third and last criterion is based on abnormal operations, considering those entities far from corporate reality, which can be observed in the following CARF trial syllabus:

BUSINESS INCORPORATION. SURPLUS
AMORTIZATION IN THE ACQUISITION
OF SHARES. SIMULATION. The corporate
reorganization, to be legitimate, must result
from effectively existing acts, not just artificial
and formally revealed in documentation or in
commercial or tax records. The characterization
of acts as simulated, and not real, authorizes the
disallowance of the amortization of recorded
surplus. ${ }^{2}$

Still, regarding the criterion of abnormal operations, it is clear that the administrative law has analysed the group of all transactions carried out and not only isolated acts of each transaction.

11 BRASIL. Ministry of Finance. Judgment n. 1803-000551. Applicant: Marcotrade Foreign Trade of Brazil Ltda. Defendant: 5th Panel of Judges of the DRJ in Sao Paulo. Drafter: Benicio Benedicto Celso Junior. Brasília, August 5, 2010. Available at: $<$ https://carf.fazenda.gov.br $>$. Entry:10 abr. 2014. Translation: "MULTA DE OFÍCIO - SUCESSÃO POR INCORPORAÇÃO - RESPONSABILIDADE DO SUCESSOR - SUCESSÃO ENTRE EMPRESAS INTEGRANTES DO MESMO GRUPO - EXONERAÇÃO - IMPOSSIBILIDADE - Tratando-se de sucessão entre empresas ligadas, coligadas ou controladas, deve-se manter a multa de ofício lançada na empresa incorporada, já que é manifesta a interveniência da incorporadora nos procedimentos da incorporada".

12 BRASIL. Ministry of Finance. Judgment n. 1803-000551. Applicant: Marcotrade Foreign Trade of Brazil Ltda. Defendant: 5th Panel of Judges of the DRJ in Sao Paulo. Drafter: Benicio Benedicto Celso Junior. Brasilia, August 5, 2010. Available at: $<$ https://carf.fazenda.gov.br $>$. Entry:10 abr. 2014. Translation: INCORPORAÇÃO DE SOCIEDADE. AMORTIZAÇÃO DE ÁGIO NA AQUISIÇÃO DE AÇÕES. SIMULAÇÃO. A reorganização societária, para ser legítima, deve decorrer de atos efetivamente existentes, e não apenas artificial e formalmente revelados em documentação ou na escrituração mercantil ou fiscal. A caracterização dos atos como simulados, e não reais, autoriza a glosa da amortização do ágio contabilizado". 
This is what is shown in the fragment of the ruling No. 1103-000.960, that deals with the succession of amending events of shareholding control in the same corporate group, without any negotiation purpose:

\begin{abstract}
In examining cases of surplus amortization, it is necessary to evaluate the set of transactions investigated, not just each one individually, so to identify the position of companies before and after the succession of facts, checking whether there was any actual change in business, organization of corporate group, or if everything remained as before artificially, creating conditions for the reduction of the calculation basis. ${ }^{13}$
\end{abstract}

The study highlights, however, that the "business purpose test" created by the CARF precedents does not always follow the same lines of the North American business purpose doctrine.

The assertion is clear when analysing the ruling No. 101-96087, on March 29, 2007. In the case presented, the tax court, when deciding on validity of an underwriting transaction and disposition of corporate shares, established the understanding that although formally legitimate, legal business must have an effective business purpose, forbidding empty forms that covet solely to circumvent the tributary prescriptive norm since such "deviations" infringe the law and fulminate the principle of the tax payers capacity.

The tax judges concluded that the negotiations must have a content in themselves so that the tax saving is be lawful. The company must assume the risks inherent to the institute adopted, showing its purpose its not merely to circumvent the application of the tax laws.

It the judgment under discussion, it seems that the business purpose employed there resembles more the figure of the abuse of rights more than the figure of the business purpose of Notrh American law. This is because the abuse of rights in the tax law has as a key feature the tax saving and the misrepresentation of the purpose of business. (SCHOUERI, 2010, p.496).

13 BRASIL. Ministry of Finance. Judgment n. 1103-000960. Appellant. Finance and National Weather Service. Drafter: Aloysio Percínio José da Silva. Brasilia, April 25, 2014.Available /at: $<$ https://carf.fazenda.gov.br>. Entry: 12 May 2014. "No exame de casos de amortização de ágio, faz necessária a avaliação do conjunto de operações investigadas, não apenas de cada uma isoladamente, de tal forma a identificar-se a situação das sociedades antes e depois da sucessão dos fatos, verificando-se se houve alguma alteração efetiva nos negócios, na organização do grupo societário, ou se tudo continuou como antes, criando-se tão somente as condições para a redução da base de cálculo artificialmente". 
It is also noteworthy is that the construction of the business purpose test, present in several CARF rulings, can also be observed, although implicity, in Brazilian judicial court rulings.

One of the most relevant cases related to the subject and addressed by the Tribunal Regional Federal da $4^{\mathrm{a}}$ Região (TRF4) was the analysis of records of apeal no. 2004.71.10.003965-9 / RS, known as "Josapar Case", a large enterprise in the food ector in the state of Rio Grande do Sul.

The issue was a reverse merger transaction, in which Supremo Industrial, holder of tax losses, incorporated Suprarroz S.A. that had gains to reduce tax losses. Subsequently, company Josapar company incorporated Suprarroz S.A. The tax liability arose from the observation of a simulated merger with another entity for the use of tax losses and the removal of levy of income tax (IRPJ) and social contribution (CSLL).

Although the Josapar company has claimed the absence of simulation, once they respected the formalities prescribed in legislation, the TRF4 understood that the merger was not economically feasible as it was performed with the sole purpose of enabling the use tax losses in the merge. The Ministério Público Federal ${ }^{14}$ (MPF) addressed the several factors that distanced the economic reality of the business. ${ }^{15}$

The Superior Tribunal de Justiça (STJ), where Josapar brought the action, confirmed the decision of the local, creating a significant precedent for the application of the business purpose doctrine in the Brazilian legal system.

Folowing this line of tought, Guilherme Costa Val Machado says:

It seems that the STJ digressed the issue and ended
up validating the use of the business purpose test
(even combined with other tests and analysis) as an
instrument, almost intrinsic to the identification of
simulated practice. This is because the analysis of
the financial statements in attention to corporate
structure and transactions practiced by the company

14 The Ministério Público Federal (MPF) has no equivalent in the United States of America or in the United Kingdom, but its attributions are similar to the Justice Department (USA) or the Crown Prosecution Service (CPS).

15 As observed in the judgment from the Federal Judge Tilling Dirceu de Almeida Soares, it is mentioned as the absence of the economic reality of the business (business purpose): the real estate developer (Supremo) who took the corporate name of the incorporated; the headquarters of the new group resulting from the operation, which become the former headquarters of the incorporated company (Suprarroz); the merging company (Supremo) which did not even have a head office; members of the Board of Directors of the merging company (Supremo) who have renounced to take over the Board of the incorporated (Suprarroz). 
the key to the understanding of the economic and social reality of the transaction that in the case was interpreted as unrealistic under such views. Would it be an economically viable business? Are there economic or logistical reasons that support the transaction? (MACHADO, 2013, p.77). ${ }^{16}$

Therefore, the STJ rejected the formalism of the law in order to implement the business purpose doctrine, requiring interest in the economic reality of the legal business investigated, showing that the simple submission of the fact to the norm requires not only the compliance with the formal and material requirements of the legal business, but also that there is no breach to the law (CAVALCANTI, 2011, p.14).

\section{BUSINESS PURPOSE AND CIVIL LAW: OBJECTIVE CAUSE OF THE LEGAL BUSINESS}

The doctrine has indicated changes that occur in the Brazilian Tax Law against the position of legality and tax types, which once prevailed with greater expression (GRECO, 2011, p.10).

The formalism as an instrument of protection for democratic values entailed the worship of the law, enabling organizations to adopt negotiation structures and purely formal corporate restructurings, that is, "corporate legal assemblies without any economic, entrepreneurial or extra-tributary substance" (GRECO, 2011, p.14).

With the advent of the 1988 Brazilian Federal Constitution, the attachment to the formal sense of the tax phenomenon should be reconsidered, mainly because the exaggerated formalism, the result of conservative and totalitarian legislation is incompatible with the "political and philosophical variable" of the Democratic State (GRECO, 2011, p.10).

In this respect, Ricardo Lobo Torres argues that the changing

16 MACHADO, Guilherme Costa Val. Planejamento tributário: o papel do "business purpose test" da "step transation doctrine" na verificação da simulação. Revista Dialética de Direito Tributário (RDDT), São Paulo, n. 211, p. 70-79, abr. 2013. p. 77. Translation: "Parece-nos que o STJ tangenciou o tema e acabou por validar a utilização do teste do propósito negocial (mesmo que aliado a outros testes e análises) como instrumento, diríamos, quase intrínseco, à identificação da prática simulada. Isso porque a análise das demonstrações contábeis em atenção à configuração societária e às operações praticadas pela empresa são essenciais à compreensão da realidade econômico-social da operação que, no caso, foi interpretada como irreal sob tais pontos de vista. Seria o negócio economicamente viável? Há razões econômicas ou logísticas que suportem a transação?". 
of the jurisprudence of concepts, which gives importance to the strict legality and in the role of the Legislative Power, to the jurisprudence of values, whose focus is the assertion of a democratic state of law, is a rupture with the old interpretations of Tributary Law (conceptualist and economic interpretation), recognizing new issues for the understanding of the Law, namely:

(a) Prominence of the fundamental principles of the Democratic State of Law, which in Brazil are expressed in art. 1 of CF: sovereignty, citizenship, human dignity, autonomy, value of labour, pluralism; b) balance between the principle of contributive capacity, linked to the idea of justice achieved by democratic argument, and the legality principle, legal certainty bound to the configuration "safety of the rule"; c) balance between state powers, with the possibility of jurisdictional control of tax policies adopted by the legislature; d) harmonization between law and economics, considering that, in addition to the fact that the economy lives sub specie juris, both show the common ethical coefficient; e) the symbiosis between teleological and systematic interpretation, according to the methodological pluralism, the legal system already segregates the purpose. (TORRES, 2012, p.14). ${ }^{17}$

In this regard, Marco Aurelio Greco advocates that the freedom of the taxpayer to self-organize their ventures is required to be reconciled with equality and ability to pay, because, for their conduct be acceptable for tax purposes it is necessary to have all acts considered and not just the isolated acts, that is:

17 TORRES, Ricardo Lobo. Planejamento tributário: elisão abusiva e evasão fiscal. Rio de Janeiro: Elsevier, 2012. Translation: “a) Preeminência dos princípios fundantes do Estado Democrático de Direito, que no Brasil se expressam no art. $1^{\circ}$ da CF: soberania, cidadania, dignidade humana, autonomia da vontade, valor do trabalho, pluralismo; b) ponderação entre o princípio da capacidade contributiva, vinculado à ideia de justiça obtido por argumentação democrática, e o princípio da legalidade, vinculado à segurança jurídica em sua configuração de 'segurança da regra'; c) equilíbrio entre os poderes do Estado, com possibilidade de controle jurisdicional de políticas fiscais adotadas pelo legislador; d) harmonização entre direito e economia, tendo em vista que, além de a economia viver sub specie juris, ambos exibem o coeficiente ético comum; a simbiose entre interpretação finalística e sistemática, eis que, de acordo com o pluralismo metodológico, o sistema jurídico já segrega a finalidade". 
The tax debate - in so many words - ceased to be a formal debate. This is not about the prevalence of substance over form, but of coexistence; it is not about overlapping, but about composing values. (GRECO, 2011, p.15). ${ }^{18}$

It can be seen from the cited speech, that the Brazilian doctrine and the tax administration are expanding the debate about formalism in the science of law, above all in the Tributary Law, which employs both descriptive and normative propositions for the construction of meanings, embracing interpretations that "seek the truth" without ignoring the actual facts, and thus allowing the practical scope of the normative text (ÁVILA, 2013, p.181).

Furthermore, it should be stressed that the 1988constitutional paradigm honoured the principle of contributive capacity, forbidding discriminatory requirements and unequal treatment between taxpayers who find themselves in comparable situations, as seen in the subsection II of art. 150 of the Constitution to pay taxes:

Notwithstanding other guarantees ensured to the taxpayer, it is forbidden for the Union, the States, the Federal District and Municipalities: II - set unequal treatment between taxpayers who find themselves in similar situation, forbid any distinction on grounds of professional occupation or role that they exert, regardless of the legal denomination of income, securities or rights. ${ }^{19}$

As Humberto Avila explains, the ability to pay, established by $\S 1^{\circ}$ of Article 145 of the 1988 Federal Constitution, was elevated to a "measure of distinction among taxpayers" for taxes aimed at particular tax purpose (ÁVILA, 2009, p.160).

18 GRECO, Marco Aurélio. Crise do formalismo no Direito Tributário brasileiro. Revista da PGFN, Brasília, ano 1, n. 1, 2011, p.14. Translation: "O debate tributário - com todas as letras - deixou de ser um debate formal. Não se trata de prevalência da substância sobre a forma, mas de coexistência; não se trata de sobre+por, mas de com+por valores".

19 BRASIL. Constituição (1988). Constituição da República Federativa do Brasil de 1988. Available at: $<$ http://www.planalto.gov.br/ccivil_03/constituicao/constituicao. htm>. Entry: Dec. 27 2013. Translation: ART. 150. Sem prejuízo de outras garantias asseguradas ao contribuinte, é vedado à União, aos Estados, ao Distrito Federal e aos Municípios: II - instituir tratamento desigual entre contribuintes que se encontrem em situação equivalente, proibida qualquer distinção em razão da ocupação profissional ou função por eles exercida, independentemente da denominação jurídica dos rendimentos, títulos ou direitos". 
For no other reason, the CARF has relativized the principle of freedom of self-organization by the constitutional principles of isonomy and ability to pay in proceedings leading to corporate reorganization, in the absence of extra-tributary motivation and among them the business purpose as the foundation for requiring tribute.

It is what can be seen on the syllabus of the ruling No. 10421497, the former Conselho de Contribuintes/CSRF, by the Counsellor Maria Helena Cotta Cardozo, at the administrative appeal brought by former governor of the State of Rio Grande do Sul:

ABSENCE OF EXTRATRIBUTARY MOTIVATION - The principle of freedom of self-organization, which was mitigated by the constitutional principles of tax equality and ability to pay, no longer endorse the practice of negotiation acts without motivation, on the grounds of tax planning. ${ }^{20}$

The same reasoning can be found on the syllabus of the decision 1302-001.108, of the First Section of Trials of the CSRF:

SELF-ORGANIZATION FREEDOM. LIMITATIONS. The freedom of self-organization of the taxpayer to the tax authorities and society is not absolute, but it is subject to constraints as the respect of free competition, good faith, the social role of the company, and does not comply with the practices of simulation, abuse of right or breach of the law. ${ }^{21}$

Certainly the principle of self-organization freedom is a result of the principle of private autonomy, and as such acknowledged by the

20 BRASIL. Ministry of Finance. Judgment n. 104-21497. Applicant: Paulo Affonso Girardi Feijo. Defendant: 4th Class / DRJ - Porto Alegre. Drafter: Maria Helena Cardoso Cotta. Brasília, 26 May 2006. Available at:<www.carf.gov.br>. Entry:13 May 2014. Translation: "AUSÊNCIA DE MOTIVAÇÃO EXTRATRIBUTÁRIA - O princípio da liberdade de auto-organização, mitigado que foi pelos princípios constitucionais da isonomia tributária e da capacidade contributiva, não mais endossa a prática de atos sem motivação negocial, sob o argumento de exercício de planejamento tributário".

21 BRASIL. Ministry of Finance. Judgment n. 1302-001108. Applicant: Agrenco of Brazil S / A. Defendant: National Treasury. Drafter: Márcio Rodrigo Frizzo. Brasilia, September 17, 2013. Available at: <www.carf.gov.br>. Entry: 14 May 2014. Translation: "LIBERDADE DE AUTO-ORGANIZAÇÃO. LIMITES. A liberdade de auto-organização do contribuinte perante o Fisco e a sociedade não é absoluta, está sujeita a restrições como o respeito à livre concorrência, à boa-fé, à função social da empresa e não se coaduna com as práticas de simulação, abuso de direito ou fraude à lei”. 
legal order as "a creative source of legal relations", empowering private individuals to conduct several economic activities subject to taxation (AZEVEDO, 2002, p.13).

In this context, the principle of private autonomy is associated with an institute of civil law that related to Tributary Law, it becomes important to the study of business purpose in the Brazilian Legal System (FREITAS, 2010, p.462).

The legal business can be differentiated by its content (object) and its cause. Whereas content is the description of the event, the cause of the legal business is the actual event that takes place by the hand of the man. The content of the legal business will be tied to the domain of the "ought" (hypothesis) and the cause, to the domain of-"is" (fact) (FREITAS, 2010, p.474).

The will and the cause are elements that are external to the legal business, so the civil rules act only as "means of correction of business". This is the view expressed by Antônio Junqueira de Azevedo:

Will and cause, as we will see, are not part of the legal business, that is, the business exists independently of them (regard to the existence); both are only means of correction of the business, in the way that they, acting out of business, either in terms of validity or in the effectiveness, prevent, sometimes more, sometimes less, the effects not wanted (that is, not wanted subjectively) by the agent - will, or not wanted objectively by juridical norm - cause) (AZEVEDO, 2002, p.22). ${ }^{22}$

Assertively, the same author explores the concept of legal business cause:

The cause is an external fact to the business, but that is what justifies the social and legal point of view, whereas the categorical element is precisely the objective reference, which makes this fact, the content of the business itself. In other words, the inalienable objective element is part, is an integral

22 AZEVEDO, Antônio Junqueira. Negócio jurídico: existência, validade e eficácia. 4. ed. São Paulo: Saraiva, 2002, p.22. Translation: “A causa é um fato externo ao negócio, mas que o justifica do ponto de vista social e jurídico, enquanto o elemento categorial objetivo é justamente a referência, que se faz a esse fato, no próprio conteúdo do negócio. Por outras palavras, o elemento inderrogável objetivo faz parte, isto é, é integrante da estrutura do negócio, e a causa, não. O elemento categorial consiste numa referência à causa, a qual está, porém, fora do negócio (ela está, logicamente, ou antes ou depois, mas não no negócio; ela é extrínseca à sua constituição)". 
part of the structure of the business, and the cause is not. The categorical element is a reference to the cause, which is, however, out of business (it is, of course, or before or after, but not in business, it is extrinsic to its constitution) (AZEVEDO, 2002, p.149). ${ }^{23}$

It is said, in other words, that the cause of the legal business is nothing more than the "reason for being" of the business, seen not only as a juridical concept - will of the law, but as a social construct. It is the practical purpose of the legal business, receiving supervision of the system since the interest pursued is intended to (social) functions of the legal business (BETTI, 2008, p.261).

Thus, it is understood that the cause of the legal business is the economic purpose intended by the parties, according to Emílio Betti:

[...] it is easy to conclude that the cause or reason of the business is identified with the economic and social function of any business, regarded deprived of judicial protection, in the synthesis of its essential elements, and as a completely functional unit, which is manifested in the private autonomy. The cause is, in short, the function of social interest of private autonomy. The element (sic) necessary for the existence of the business are also essential elements of the typical function that is its characteristic. Their synthesis represents the type of business to the extent that is causal business, and it is an equally typical function. The economic and social function of the type of business, as an expression of private autonomy, which is a social phenomenon before becoming, with acknowledgment, a legal fact (BETTI, 2008, p.264). ${ }^{24}$

23 Ibid., p.149. Translation: “A causa é um fato externo ao negócio, mas que o justifica do ponto de vista social e jurídico, enquanto o elemento categorial objetivo é justamente a referência, que se faz a esse fato, no próprio conteúdo do negócio. Por outras palavras, o elemento inderrogável objetivo faz parte, isto é, é integrante da estrutura do negócio, e a causa, não. $\mathrm{O}$ elemento categorial consiste numa referência à causa, a qual está, porém, fora do negócio (ela está, logicamente, ou antes ou depois, mas não no negócio; ela é extrínseca à sua constituição). 24 BETTI, Emílio. Teoria geral do negócio jurídico. Campinas: Servanda, 2008, p.261. Translation: "[...] é fácil concluir que a causa ou razão do negócio se identifica com a função econômico-social de todo o negócio, considerado despojado da tutela jurídica, na síntese dos seus elementos essenciais, como totalidade e unidade funcional, em que se manifesta a autonomia privada. A causa é, em resumo, a função de interesse social da autonomia privada. Os elemento (sic) necessários para a existência do negócio são também elementos indispensáveis 
Yet, when considered in its social aspect, according to the same author, "the cause of the business is properly the social economic function, which characterizes this type of business as a fact of private autonomy (typical, in this sense), and it determines its minimum necessary content" (BETTI, 2008, p.265).

The best doctrine classifies the cause with typical economic purpose of objective cause, since the legal business endowed with such purpose, by the social interest that resident therein, demands a practical adoption. Hence, it is said that the objective cause is implemented in practice (SCHOUERI, 2010, p.477).

Based in this understanding, the theory of the business purpose is supported in the tort part of the objective cause of the legal business (objective final will of the legal business), which is why the doctrine and the tax administrative jurisprudence has recognized the institute's business purpose as the very objective of the legal business, as it denotes the summaries transcribed below:

TAX PLANNING. REASON FOR BUSINESS. BUSINESS CAUSE. LEGALITY. Reason of business is the subjective reason why the taxpayer does the legal business. Cause of their economic or business function is the effect that the business produces in the legal spheres of participants. The illegal motive implies invalidity when declared by a Judge. If the business motivation is tax savings, you cannot talk on illegal motive. ${ }^{25}$

TAX PLANNING. REASON FOR BUSINESS. ECONOMIC CONTENT. BUSINESS PURPOSE. LEGALITY. There is no federal or national rule, which considers absent or ineffective legal business

da função típica que é sua característica. A sua síntese, assim como representa o tipo de negócio, na medida em que é negócio causal, também lhe representa igualmente função típica. Função econômico-social do tipo de negócio, como manifestação de autonomia privada, a qual é um fenômeno social antes de se tornar, com reconhecimento, um fato jurídico".

25 BRASIL. Ministry of Finance. Judgment n. 1101-000835. Applicant: Termopernanbuco S / A. Defendant: National Treasury. Drafter: Edeli Pereira Bessa. Brasília, December 4, 2012. Available at: <www.carf.gov.br>. Entry: 15 May 2014. Translation: "PLANEJAMENTO TRIBUTÁRIO. MOTIVO DO NEGÓCIO. CONTEÚDO ECONÔMICO. PROPÓSITO NEGOCIAL. LICITUDE. Não existe regra federal ou nacional que considere negócio jurídico inexistente ou sem efeito se o motivo de sua prática foi apenas economia tributária. Não tem amparo no sistema jurídico a tese de que negócios motivados por economia fiscal não teriam 'conteúdo econômico' ou 'propósito negocial' e poderiam ser desconsiderados pela fiscalização. O lançamento deve ser feito nos termos da lei”. 
whose reason for their practice was only tax savings. It is not supported by the legal system the thesis that business motivated by tax savings would not have "financial nature" or "business purpose" and could be disregarded by enforcement. The tax levy should be done in accordance with the law. ${ }^{26}$

TAX PLANNING - CRITERIA. What determines the incidence of tribute or not, for the characterization of tributary planning, is the function to which the operation within the economic enterprise is designated (objective cause - business purpose), not simply the existence of the formal content of the legal business, embodied in the declaration of intent. ${ }^{27}$

In view of this, it is justified that the tax planning can be guided by analysis of the business purpose, if this is qualified as an element that forms the objective cause of the legal business (social economic purpose). (SCHOUERI, 2010, p.488).

It is important to mention, however, that the business purpose should be shaped to the objective criteria related to the elements that compose the legal transaction, considering that not every extratributary justification can be urged against the Treasury.

In short, is not for the tax administration any extratributary requirements, but only those that justify the objective cause of legal transaction (SCHOUERI, 2010, p.488).

\section{FinAl CONSIDERATIONS}

It is understood, therefore, that the doctrine of business purpose can be recognized and enforced in the Brazilian legal system, although

26 BRASIL. Ministry of Finance. Judgment n. 1101-000841. Applicant: Companhia Energética do Rio Grande do Norte - COSERN. Defendant: National Treasury. Drafter: Edeli Pereira Bessa. Brasilia, December 6, 2012. Available at :<www.carf.gov.br $>$. Entry: 15 May 2014. Translation: "PLANEJAMENTO TRIBUTÁRIO - CRITÉRIOS. O que determina a incidência ou não de tributo para caracterização de planejamento tributário é a função que se destina a operação dentro do empreendimento econômico (causa objetiva - propósito negocial), não bastando a existência do conteúdo formal do negócio jurídico, consubstanciado na declaração de vontade".

27 BRASIL. Ministry of Finance. Judgment n. 1202-001076. Applicant: New Storeroom Participações Ltda. Defendant: National Treasury. Drafter: Valentim Geraldo Neto. Brasília, February 10, 2014. Available at :<www.carf.gov.br>. Entry: 15 May 2014. 
there is no express provision of the institute in the Brazilian legislation. This can be supported because the constitutional principles from the Republican Constitution of 1988, in particular the principle of the social function of property and the ability to pay, imposed limitations on business operations, enabling the legal rules to raise the business purpose as a valid institute for tax avoidance.

Moreover, the introduction of the sole paragraph of art. 116 of the CTN inserted in the national legislation the norm of tax avoidance, enabling the state, through tax administration service, to disregard acts or covert legal transactions used to conceal the generator of the tribute or elements that constitute the tax obligation.

It is noteworthy, therefore, that there is no obstacle to that the test of the business utility to be considered assumption of evasion practice, mainly regarding the analysis of tax avoidance in corporate transactions, thereby contributing to the transparency in tax planning that aims to reducing the tax burden within a correct interpretation of tributary law.

Some of the scholars still define it as "more of a foreign theory invading the Ordering", it was shown that the business utility, by finding support in the institute of the objective cause of the legal business, rule out, by itself, this obtuse reasoning.

Both North American and Brazilian jurisprudence are useful to corroborate the tax planning, and here is inserted tax avoidance, which need new legal instruments to stop the abusive conduct of corporate legal affairs. This does not mean that the taxpayer is prohibited from adopting behaviours that are most suitable to them, under a tax standpoint. What is required of them is only exercise their rights to tax savings and act within the parameters imposed by the social function of contracts by negotiating bona fide, seal the abuse of rights or forms of evasion of the law and absence of reasons.

Far from being finished and opening space for future discussions, we sought herein to demonstrate the plausibility of adopting business purpose by the criteria employed by the administrative courts. First, because in the Brazilian legal framework the figure can be identified as the cause of legal transaction, and second, because the clauses in civil law determine that the acts and legal transactions arising from private autonomy - and among these we can include tax planning - require a negotiating reason, so as to meet the constitutional principles and the new constitutional order established in the Constitution of 1988.

\section{REFERENCE}

ABRAHAM, Marcus. Os 10 anos da norma geral e as cláusulas do propósito negocial e da substância sobre a forma presentes no direito 
brasileiro. Revista Dialética de Direito Tributário (RDDT), São Paulo: Dialética, 2011.

ALEMANHA. Abgabenordung (AO), de 16 de março de 1976. Código Tributário Alemão. Available at: $<$ http://www.gesetze-im-internet. de/ao_1977/BJNR006130976.html>. Entry:02 de May de 2014. A tradução é de Alfred J. Schmidt, conforme Ricardo Lobo Torres em 'TORRES, Ricardo Lobo. Normas gerais. Revista Eletrônica de Direito Administrativo Econômico, Salvador, Bahia, n. 4, nov./dez. 2006. Available at $:<$ http://www.direitodoestado.com/revista/REDAE4-NOVEMBRO-2005-ICARDO\%20LOBO\%20TORRES.pdf $>$. Entry: May 02, 2014

AMARAL, Antonio Carlos Rodrigues. Curso de Direito Tributário. São Paulo: Celso Bastos, 2002. p. 294.

ANDRADE FILHO, Edmar Oliveira. Planejamento tributário. São Paulo: Saraiva, 2009. p. 200.

ANGELO, Carlos Eduardo Peroba. Aplicação dos conceitos de planejamento tributário na jurisprudência do antigo Conselho de Contribuintes e doutrina. In: SCHOUERI, Luís Eduardo (Coord.); FREITAS, Rodrigo de (Org.). Planejamento tributário e o "propósito negocial". São Paulo: Quartier Latin, 2010.

ÁVILA, Humberto Bergmann. Teoria da igualdade tributária. São Paulo: Malheiros, 2009.

ÁVILA, Humberto Bergmann. Função da ciência do direito tributário: do formalismo epistemológico ao estruturalismo argumentativo. Revista Direito Tributário Atual, São Paulo: Dialética, 2013.

AZEVEDO, Antônio Junqueira. Negócio jurídico: existência, validade e eficácia. 4. ed. São Paulo: Saraiva, 2002.

BETTI, Emílio. Teoria geral do negócio jurídico. Campinas: Servanda, 2008.

BRASIL. Constituição (1988). Constituição da República Federativa do Brasil de 1988. Available at: $<$ http://www.planalto.gov.br/ccivil_03/ constituicao/constituicao.htm>. Entry: Dec. 272013.

BRASIL. Tribunal Regional Federal (4. Região). Apelação $\mathbf{n}^{0}$ 2004.71.10.003965-9. Apelante: JOSAPAR Joaquim Oliveira S/A Participações. Apelado: União Federal (Fazenda Nacional). Relator: Desembargador Dirceu de Almeida Soares. Porto Alegre, 06 de setembro de 2006. Available at: $<$ http://www2.trf4.gov.br/trf4/processos/ visualizar documento ged pro.php?local $=\operatorname{trf} 4 \&$ documento $=1254430$

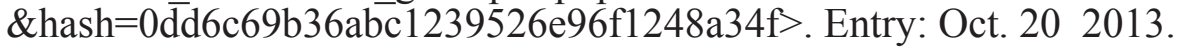


BRASIL. Lei $\mathbf{n}^{\mathbf{0}} \mathbf{1 0 . 4 0 6}$, de 10 de janeiro de 2002. Institui o Código Civil. Available at: <http://www.planalto.gov.br/ccivil_03/leis/2002/ 110406.htm>. Entry:08 mar. 2014.

BRASIL. Lei 5.172, de 25 de outubro de 1966. Dispõe sobre o Sistema Tributário Nacional e institui normas gerais de direito tributário aplicáveis à União, Estados e Municípios. Available at:

$<$ http://www.planalto.gov.br/ccivil_03/leis/15172.htm>. Entry: May 04,2014

BRASIL. Medida provisória $\mathbf{n}^{0}$ 66, de 29 de agosto de 2002. Dispõe sobre os procedimentos para desconsideração de atos ou negócios jurídicos, para fins tributários. Available at:

$<$ http://www.receita.fazenda.gov.br/Legislacao/MPs/2002/mp66.htm>. Entry: May 11, 2014.

BRASIL. Ministério da Fazenda. Acórdão n. 101-96.087. Recorrente: Cooperativa Central de Laticínios do Paraná Ltda. Recorrido: $1^{\text {a }}$ Turma da DRJ em Curtiba. Relator: Mário Junqueira Franco Júnior. Brasília, 29 de março de 2007. Available at: $<$ https://carf.fazenda.gov.br $>$. Entry: May 122014.

BRASIL. Ministério da Fazenda. Acórdão n. 1202-001.076. Recorrente: Nova Paiol Participações Ltda. Recorrido: Fazenda Nacional. Relator: Geraldo Valentim Neto. Brasília, 10 de fevereiro de 2014. Available at: <www.carf.gov.br $>$. Entry:15 May 2014.

BRASIL. Ministério da Fazenda. Acórdão n. 1302-001.108. Recorrente: Agrenco do Brasil S/A. Recorrido: Fazenda Nacional. Relator: Márcio Rodrigo Frizzo. Brasília, 17 de setembro de 2013. Available at: $<$ www. carf.gov.br>. Entry:14 May 2014.

BRASIL. Ministério da Fazenda. Acórdão n. 104-21.497. Recorrente: Paulo Affonso Girardi Feijó. Recorrido: 4a Turma / DRJ - Porto Alegre. Relator: Maria Helena Cotta Cardoso. Brasília, 26 de May de 2006. Available at:<www.carf.gov.br>. Entry:13 May 2014.

BRASIL. Ministério da Fazenda. Acórdão n. 1101-000.841. Recorrente: Companhia Energética do Rio Grande do Norte - COSERN. Recorrido: Fazenda Nacional. Relator: Edeli Pereira Bessa. Brasília, 06 de dezembro de 2012. Available at:<www.carf.gov.br>. Entry:15 May 2014.

BRASIL. Ministério da Fazenda. Acórdão n. 1101-000.835. Recorrente: Termopernanbuco S/A. Recorrido: Fazenda Nacional. Relator: Edeli Pereira Bessa. Brasília, 04 de dezembro de 2012. Available at: $<$ www. carf.gov.br>. Entry:15 May 2014. 
BRASIL. Ministério da Fazenda. Acórdão n. 103-21047. Recorrente: JOSAPAR - Joaquim Oliveira SA Participações. Recorrido: Fazenda Nacional. Relator: Paschoal Raucci. Brasília, 16 de outubro de 2002. Available at: $<$ https://carf.fazenda.gov.br $>$. Entry:12 May 2014.

BRASIL. Ministério da Fazenda. Acórdão n. 1103-000.960. Recorrente. Fazenda Nacional e Tempo Serviços. Relator: Aloysio José Percínio da Silva. Brasília, 25 de abril de 2014. Available at: $<$ https://carf.fazenda. gov.br>. Entry:12 May 2014.

BRASIL. Ministério da Fazenda. Acórdão n. 1803-000.551. Recorrente: Marcotrade Comércio Exterior do Brasil Ltda. Recorrido: $5^{\mathrm{a}}$ Turma de Julgamento da DRJ em São Paulo. Relator: Benedicto Celso Benício Junior. Brasília, 05 de agosto de 2010. Available at: $<$ https://carf.fazenda. gov.br>. Entry:10 abr. 2014.

BRASIL. Ministério da Fazenda. Acórdão n. 101-96066. Recorrente: Marambaia Capital S/A. Recorrido: $7^{\mathrm{a}}$ Turma de Julgamento da DRJ no Rio de Janeiro. Relator: Sandra Maria Faroni. Brasília, 29 de março de 2007. Available at: $<$ https://carf.fazenda.gov.br>. Entry:12 May 2014.

BRASIL. Ministério da Fazenda. Acórdão n. 106-14486. Recorrente: Marina Varga de Carvalho. Recorrido: $3^{\mathrm{a}}$ Turma DRJ em Brasília. Relator: Sueli Efigênia Mendes de Britto. Brasília, 16 de março de 2005. Available at: $<$ https://carf.fazenda.gov.br $>$. Entry:12 May 2014.

CAMPOS, Diogo Leite. Elisão fiscal e Direito Civil. Revista Iberoamericana de Direito Público (RIADP), Rio de Janeiro, 2007.

CARRAZA, Antonio Roque. Curso de Direito Constitucional tributário. 26. ed. São Paulo: Malheiros, 2010. p. 278.

CARVAlHO, Cristiano; JOBIM, Eduardo de L. S. O novo Código Civil brasileiro e a elisão fiscal: possibilidade de desconsideração de formas jurídicas pelos juízes através da utilização de cláusulas gerais. In: PEIXOTO, Marcelo Magalhães; FERNANDES, Edison Carlos (Coord.). Tributação, justiça e liberdade. Curitiba: Juruá, 2005.

CAVALCANTI, Mirquelam Chaves. O propósito negocial e o planejamento tributário no ordenamento jurídico brasileiro. Revista da PGFN, Brasília, ano 1, n. 1, p. 14, 2011.

DÓRIA, Antonio Roberto Sampaio. Elisão e evasão fiscal. São Paulo: Bushatsky, 1977. p. 78.

ESPANHA. Lei 25, de 20 de julho de 1995. Dispõe sobre a modificação parcial da Ley General Tributária. Available at: $<$ http://legislacion. derecho.com/ley-25-1995-de-modificacion-parcial-de-la-ley-generaltributaria>. Entry: May 04, 2014 
ESTADOS UNIDOS. United States Court of Appeals, 10th Disctrict (Denver). True $v$. United States. No 98-8015. Judge Wade Brorby. Decidido em: 09 set. 1999. Publicado no 190 F3d 1165. Available at:

$<$ https://a.next.westlaw.com/Document/>. Entry: 09 May 2014.

ESTADOS UNIDOS. Suprema Corte dos Estados Unidos. Gregory v. Helvering, Comissioner of Internal Revenue. $\mathrm{N}^{\mathrm{o}}$ 127. Mr. Justice Sutherland. Decidido em 07/01/1935. Publicado no 55 S.Ct. 266. Available at:

$<$ https://a.next.westlaw.com/Document/I47>. Entry:15 out. 2013.

FERREIRA, Aurélio Buarque de Holanda. Novo Dicionário da Língua Portuguesa. Rio de Janeiro: Nova Fronteira, 1986. p. 483.

FREITAS, Rodrigo. É legítimo economizar tributos? Propósito negocial, causa do negócio jurídico e análise das decisões do antigo Conselho de Contribuintes. In: SCHOUERI, Luís Eduardo (Coord.); FREITAS, Rodrigo de (Org.). Planejamento tributário e o "propósito negocial". São Paulo: Quartier Latin, 2010.

GODOY, Arnaldo Sampaio Moraes. Interpretação econômica do direito tributário: o caso Gregory v. Helvering e as doutrinas do propósito negocial (business purpose) e da substância sobre a forma (substance over form). Revista Fórum de Direito Tributário (RFDT), Belo Horizonte, n. 01, p. 61, jan./fev. 2003.

GOMES, Marcus Lívio; ANTONELLI, Leonardo Pietro (Coord.). Curso de Direito Tributário Brasileiro. São Paulo: Quartier Latin, 2005. p. 503.

GRECO, Marco Aurélio. Crise do formalismo no Direito Tributário brasileiro. Revista da PGFN, Brasília, ano 1, n. 1, 2011.

HUCK, Hermes Marcelo. Evasão e elisão: rotas nacionais e internacionais do planejamento tributário. São Paulo: Saraiva, 1997. p. 49.

JONES, Sally M. Federal Taxes and management decisions. New York: Irwin Mcgraw-Hill, 1999. p. 73.

LENZ, Raoul. Elusão fiscal e a apreciação econômica dos fatos. In: TAVOLARO, Agostinho Toffoli; MACHADO, Brandão; MARTINS, Ives Grandra da Silva (Coords.). Princípios tributários no Direito Brasileiro e comparado. Rio de Janeiro: Forense, 1988. p. 586-602. p. 588.

MACEDO JÚNIOR, Ronaldo Porto. Interpretação da boa-fé nos contratos brasileiros: os princípios jurídicos em uma abordagem relacional (contra a euforia principiológica). In: MACEDO JÚNIOR, Ronaldo Porto; BARBIERI, Catarina Helena Cortada (Org.). Direito e 
interpretação: racionalidades e instituições. São Paulo: Saraiva, 2011.

MACHADO, Guilherme Costa Val. Planejamento tributário: o papel do "business purpose test" da "step transation doctrine" na verificação da simulação. Revista Dialética de Direito Tributário (RDDT), São Paulo, n. 211, p. 70-79, abr. 2013. p. 77.

MACHADO, Hugo de Brito. A Falta de Propósito Negocial como Fundamento para a Exigência de Tributo. Revista Dialética de Direito Tributário (RDDT), São Paulo, n. 143, p. 48-53, ago. 2007. p. 51.

PORTO, Ingrid Aragão Freitas. A tipicidade aberta e a interpretação econômica no direito tributário. In: JORNADA DE DIREITO TRIBUTÁRIO. TRIBUNAL REGIONAL FEDERAL DA $1^{\mathrm{a}}$ REGIÃO, 2. Escola de Magistratura Federal da $1^{\mathrm{a}}$ Região. Brasília: ESMAF, 2012. p. 155.

PORTUGAL. Decreto-Lei 398, de 17 de dezembro de 1998. Aprova a lei geral tributária que enuncia e define os princípios gerais que regem o direito fiscal e os poderes da administração tributária e garantia dos contribuintes. Disponível em: $<$ ht t p:// info . portaldasfinancas.gov.pt/NR/rdonlyres/87CAB3CA-4ED1-411A9BDE3E9725C24F21/0/LGT_01_2014.pdf>. Entry: May 04,2014

ROSEMBUJ, Tulio. El fraude de ley, la simulación y el abuso de las formas em el derecho tributário. 2. ed. Madrid: Marcial Pons, 1999. p. 261.

SEIXAS FILHO, Aurélio Pitanga. A interpretação econômica no direito tributário e os limites do planejamento tributário. Revista Fórum de Direito Tributário (RFDT), Belo Horizonte, n. 01, p. 163, jan./fev. 2003.

SCHOUERI, Luís Eduardo (Coord.); FREITAS, Rodrigo de (Org.). Planejamento tributário e 0 "propósito negocial". São Paulo: Quartier Latin, 2010. p. 482.

TORRES, Ricardo Lobo. Planejamento tributário: elisão abusiva e evasão fiscal. Rio de Janeiro: Elsevier, 2012.

TORRES, Ricardo Lobo. Normas gerais norm of tax avoidance. Revista Eletrônica de Direito Administrativo Econômico,

Salvador, Bahia, n. 4, nov./dez. 2006. Available at:<http://www. direitodoestado.com/revista/REDAE-4-NOVEMBRO2005 ICARDO\%20LOBO\% 20TORRES.pdf>. Entry: May 02, 2014

WALD, Arnaldo. Direito Civil: direito das obrigações e teoria geral dos contratos. 20. ed. São Paulo: Saraiva, 2011. 